\title{
Analisa Kinerja Perbankan Syariah Indonesia Ditinjau Dari Maqasyid Syariah
}

\author{
Mohammad Taufik Azis \\ Fakultas Ekonomi \\ Universitas Muhammadiyah Cirebon \\ Email: taufikazis80@gmail.com
}

\begin{abstract}
Abstrak
Kinerja perbankan syariah tidak hanya terdiri dari aspek keuangan, tetapi juga dilihat dari aspek syariah atau muqasyid syariah. Sehingga pengukuran kinerja bank syariah dari aspek syariah merupakan sesuatu yang penting dan diperlukan dalam mengukur kinerja perbankan syariah.

Penelitan ini bertujuan untuk menganalisa kinerja perbankan syariah di Indonesia dilihat dari aspek muqosyd syariah dengan menggunakan Index Muqasyid Syariah ( IMS ). Objek penelitan yang di gunakan adalah 11 bank dari 12 bank syariah di Indonesia. Data yang digunakan berdasarkan laporan tahunan kesebelas bank tersebut dari periode 2011 - 2015.

Hasil penelitian ini menunjukan bahwa pengukuran kinerja keuangan dapat dilakukan dengan pendekatan model IMS. Hasil penelitan ini menunjukan bahwa Bank Panin Syariah berada di tingkat pertama dan Bank Mega Syariah berada di tingkat kesebelas dalam model Index Muqasyid Syariah.
\end{abstract}

Kata kunci : Perbankan Syariah, Muqasyid Syariah

\begin{abstract}
Sharia banking performance not only consists of financial aspects, but also seen from the aspect of sharia or muqasyid sharia. So that the measurement of Islamic banking performance from the aspect of sharia is something that is important and necessary in measuring the performance of sharia banking.

This research aims to analyze the performance of Islamic banking in Indonesia viewed from the aspect of muqosyd syariah using Index Muqasyid Syariah (IMS). The research object used is 11 banks from 12 sharia banks in Indonesia. The data used is based on the eleventh annual bank report from the period 2011 - 2015.

The results of this study indicate that the measurement of financial performance can be done with the IMS model approach. The results of this research show that Bank Panin Syariah is at the first level and Bank Mega Syariah is at the eleventh level in Index Muqasyid Syariah model.
\end{abstract}

Keywords: Sharia Banking, Muqasyid Syariah 


\section{Pendahuluan}

Perbankan syariah adalah salah satu representasiaplikasi dari ekonomi Islam yang melarang penggunaan sistem bunga dalam perekonomian khususnya perbankan, karena sistem tersebut dianggap riba yang dilarang oleh agama.Bahkan pelarangan riba ini tidak hanya dari agama Islam saja tetapi juga dari agama-agama lainnya.Hal ini disebabkan karena penerapan sistem ribawiakan membawa kerusakan moral di masyarakat.

Perkembangan perbankan syariah diindonesia dari Mutahun ke tahun semakinmeningkat dengan adanya Bank umum syariah (BUS) dan Unit usaha syariah (UUS) berdasarkan outlook perbankan syariah 2015, bank umum syariah (bus ) sejumlah 12 , unit usaha syariah (uus ) sejumlah 23 dan BPRS sejumlah 160 , dengan total asset sebesar Rp 296.262 Milyar ${ }^{1}$. Industri keuangan syariah khususnya sektor perbankan, tumbuh $15 \%$ setiap tahunnya, Meski di Indonesia market share perbankan syariah masih dibawah 5\%, namun bank syariah telah memiliki 2.301 kantor yang tersebar di 33 provinsi seluruh Indonesia. Memang apabila dibandingkan dengan total aset perbankan nasional, aset perbankan syariah masih sangat kecil.

Pertumbuhan aset yang positif ini mengindikasikan perbankan syariah dapat mengelola manajemen likuiditasnya sehingga jumlah asetnya terus bertambah. Begitu pula dana pihak ketiga (DPK) yang terkumpul sebanyak Rp 231.175 Milyar, atau 1,61\% dari total

1 Otoritas Jasa Keuangan. (2016). Statistik Perbankan Syariah.Diakses melalui http:// www.ojk.go.id pada pukul 09.00 tanggal 27 Agustus 2016 dana pihak ketiga perbankan nasional. Dengan pertumbuhan dana pihak ketiga yang positif ini mengindikasikan bahwa perbankan syariah dapat memaksimalkan produk yang ditawarkan, berarti masyarakat mulai melihat keuntungan dari produk yang ditawarkan. Selain dari produk yang ditawarkan kenaikan DPK sampai saat ini dikarenakan juga oleh fatwa yang dikeluarkan Dewan Syariah Nasional (DNS) mengenai haramnya bunga bank. Dan jumlah pembiayaan perbankan syariah mencapai 75.533 milyar atau $2,58 \%$ dari total pembiayaan/kredit yang disalurkan perbankan nasional. Dengan pertumbuhan pembiayaan yang positif mengindikasikan perbankan syariah dapat melakukan fungsi sebagai lembaga intermediasi dengan baik.

Pelakasanaan maqasyid syariah oleh perbankan syariah telah menjadi perhatian beberapa peneliti ekonomi syariah meskipun jumlahnya masih sangat minim, diantaranya adalah Omar Muhammed dalam penelitiannya (The Performance Measures of Islamic Banking Based On The Maqosid Framework) ${ }^{2}$, merumuskan sebuah pengukuran yang berguna untuk mengukur kinerja perbankan syariah yang dikembangkan berdasarkan prinsipprinsip maqasyid syariah dengan tujuan agar ada sebuah pengukuran bagi bank syariah yang sesuai dengan tujuannya.

Tujuan utama syariah adalah untuk mendorong kesejahteraan manusia yang terletak kepada keimanan, jiwa, akal, keturunan dan harta. Ulama -

\footnotetext{
2 Mohammed, Mustafa Omar dan Taib, Fauziah Md. (2009). Testing the performance Measured Based on maqashid Framework Shariah (PPMS). Model on 24 Selected Islamic and Conventional Bank.
} 
ulama Islam menyepakati kelima aspek tersebut menjadi tujuan utama yang harus diperhatikan. Bagi pemerintah, kesejahteraan semua masyarakat merupakan tujuan akhir dari pembangunan. Bagi perusahaan, kesejahteraan shareholder, stakeholder dan lingkungan social merupakan tujuan yang harus dicapai. Maqasyid syariah menjadi acuan dan panduan dalam melakukan semua aktivitas dalam bermuamalah. ${ }^{3}$

Kinerja perbankan syariah selama ini banyak di teliti menggunakan rasio - rasio konvensional sehingga perlu dilakukan evaluasi terkait tujuan mereka agar sesuai dengan muqasyid syariah.Disamping itu kehadiran bank konvensional yang terlebih dahulu hadir dibandingkan bank syariah, menyebabkan masyarakat seringkali membandingkan antara bank syariah dengan bank konvensional. Sehingga seringkalimasyarakat menyamakan antara bagi hasil bank syariah dengan bunga di bank konvensional, sehingga menimbulkan persepsi dimasyarakat tidak ada perbedaan antara bank konvensional dengan bank syariah. Dari uraian tersebut maka penulis bermaksud untuk meneliti kinerja perbankan syariah dengan menggunakan Index Muqasyid Syariah.

Berdasarkan latar belakang diatas, maka dapat dirumuskan tujuan serta permasalahan yang akan diteliti dalam penelitian ini, yaitu: Bagaimana kinerja perbankan syariah indonesia di tinjau dari Muqasyid shariah?

3 Bedoui, M.H.\&Mansourt, W. 2013.Islamic Bank Performance and Maqasid Syariah.Asia Pacific Economic Association Conference, Osaka - Jepang, $27-28$ Juli 2013.
Pembahasan

\section{Telaah Pustaka}

\section{Syariah Enterprise Theory (SET)}

Menurut Triyuwono (2007)

dikembangkan berdasarkan pada metafora zakat yang berkarakter keseimbangan. Dalam syariah Islam, bentuk keseimbangan tersebut secara konkrit diwujudkan dalam salah satu bentuk ibadah, yaitu zakat. Zakat (yang kemudian dimetaforakan menjadi metafora zakat) secara implisit mengandung nilai egoistik-altruistik, materispiritual, dan individu-jamaah.

Konsekuensi dari nilai keseimbangan ini menyebabkan SET tidak hanya peduli pada kepentingan individu (dalam hal ini pemegang saham), tetapi juga pihakpihak lainnya.Oleh karena itu, SET memiliki kepedulian yang besar pada stakeholders yang luas. Menurut SET, stakeholdersmeliputi Tuhan, manusia, dan alam. Tuhan merupakan pihak paling tinggi dan menjadi satu-satunya tujuan hidup manusia.Dengan menempatkan Tuhan sebagai stakeholder tertinggi, maka tali penghubung agar akuntansi syariah tetap bertujuan pada membangkitkan kesadaran keTuhanan para penggunanya tetap terjamin.Konsekuensi menetapkan Tuhan sebagai stakeholder tertinggi adalah digunakannya sunnatullah sebagai basis bagi konstruksi akuntansi syariah.Sehingga dengan adanya sunatullah ini maka akuntansi syariah di bangun berdasarkan pada aturan atau hukum - hukum islam. 


\section{Bank Syariah}

Berdasarkan Undang-undang No.7 Tahun 1992 tentang Perbankan sebagaimana telah diubah dengan Undang-undang No.10 Tahun 1998, jenis bank di Indonesia terdiri dari dua kelompok yaitu bank umum dan bank perkreditan rakyat (BPR). Dalam UU tersebut dijelaskan bahwa bank umum adalah bank yang melaksanakan kegiatan usaha secara konvensional dan/atau berdasarkan Prinsip Syariah yang dalam kegiatannya memberikan jasa dalam lalu lintas pembayaran. Dalam menjalankan kegiatan usahanya bank umum dapat memilih satu dari tiga pilihan yaitu seluruhnya beroperasi secara konvensional, seluruhnya beroperasi secara syariah, atau melakukan kegiatan usaha secara konvensional sekaligus juga melakukan kegiatan usaha berdasarkan prinsip syariah (dual system bank).

\section{Muqasyid Syariah}

Moqasid syariah dipopulerkan oleh Imam Syatibi dengan merumuskan konsep muqosid dengan konsep yang logis, sistematis dan komprehensif, sehingga mendapat julukan bapak maqasid syariah. Tujuan dalam islam yaitu untuk kemaslahatan umat. Menurut Jauhar (2011), Sakriman (2012) dan Mingka (2013). Yang membagi muqasyid syariah menjad 5 tujuan yaitu perlindungan terhadap agama, perlindungan jiwa, perlindungan terhadap akal, perlindungan terhadap kehormatan dan perlingunan terhadap harta.

\section{Indeks Muqasyid Syariah}

Penelitian ini merupakan penelitan kuantitatif deskriptif dengan menggunakan pendekatan konsep sekaran yaitu Operationalization Methode dan Model Sharia Index ((MSI) Mustofa Omar Mohammad dan Dzuljastri Abdul Razak (2008) ${ }^{4}$.

\section{Pengukuran Metode kerja}

Teknik pengumpulan data dalam penelitian ini dilakukan dengan metode arcvival research (penelitian arsip) yaitu pengumpulan data yang umumnya berupa bukti, catatan atau laporan historis.

Metode pengukuran maqasid syarariah yang digunakan dalam penelitian ini adalah model pengukuran maqasid syariah yang dibut dan digunakan oleh Mustafa omar dan Dzulastri Abdul Rojak (2008 dan 2010) dalam mengukur kinerja perbankan syariah dalam bentuk Index Muqasyid Syariah (IMS) yang berasal dari konsep maqasid syariah yang dijelaskan oleh Imam Abu Zahrah.

\footnotetext{
${ }^{4}$ Mohammed, Dzuljastri dan Taib (2008).The Performance of Islamic Banking Based on The Maqashid Frammework.Makalah disampaikan pada IIUM International Accounting Conference (INTAC IV). Putra Jaya Marroit. Malaysia. 25 Juni 2015
} 
Teori Maqasid Syariah oleh Abu Zahra meliputi Tahdzib alFard (mendidik individu), Iqamah $\mathrm{Al}$-Adl (keadilan menetapkan), dan Maslahah (kesejahteraan). Melalui sekaran koncept, ketiga maqasid telah diterjemahkan ke dalam dimensi dan kemudian diklasifikasikan menjadi beberapa elemen (Mohammed, 2015).
Untuk mendapatkan Dimensi, Elemen Pengukuran dan Rasio Kinerja, maka dilakukan interview terhadap 12 pakar yang memahami masalah perbankan , fikih ekonomi dan keuangan syariah di asia tenggara dan timur tengah ( omar, 2008 ), sehingga didapat model pengukuran kinerja muqasid syariah sebagai berikut:

Tabel 1: Model Pengukuran Kinerja Muqasyid Syariah

\begin{tabular}{|c|c|c|c|c|}
\hline $\begin{array}{l}\text { Tujuan } \\
\text { Syariah }\end{array}$ & Dimensi ( D ) & Elemen ( $\mathrm{E}$ ) & Rasio Kinerja (K) & $\begin{array}{l}\text { Sumber } \\
\text { Data }\end{array}$ \\
\hline \multirow{4}{*}{$\begin{array}{l}\text { Mendidik } \\
\text { Individu }\end{array}$} & D1. Pengembangan & E1. Pendidikan & R1. Biaya Diklat / & \\
\hline & Pengetahuan & dan pelatihan & Total Biaya & \\
\hline & & E2. Penelitian & $\begin{array}{l}\text { R2. Biaya Penelitian / } \\
\text { Total Biaya }\end{array}$ & \\
\hline & $\begin{array}{l}\text { D2. masyarakat mengetahui } \\
\text { bank syariah }\end{array}$ & E3. Publisitas & $\begin{array}{l}\text { R3. Biaya Publisitas / } \\
\text { Total Biaya }\end{array}$ & \\
\hline \multirow[t]{5}{*}{$\begin{array}{c}\text { Mewujudkan } \\
\text { Keadilan }\end{array}$} & D3. Kontrak yang adil & $\begin{array}{l}\text { E4. Pengembalian } \\
\text { yang adil }\end{array}$ & $\begin{array}{l}\text { R4. Laba / } \\
\text { Total Pendapatan }\end{array}$ & $\begin{array}{l}\text { Laporan } \\
\text { Tahunan }\end{array}$ \\
\hline & D4. Produk dan & E5. Distribusi & R5. Pembiayaan mudhorobah & \\
\hline & jasa yang terjangkau & Fungsional & \& Musyarokah/Total Investasi & \\
\hline & D5. Penghapusan atas & E6. Produk bank & R6. Pendapatan non bunga / & \\
\hline & Ketidakadilan & non bunga & Total pendapatan & \\
\hline \multirow[t]{3}{*}{$\begin{array}{l}\text { Kepentingan } \\
\text { Publik }\end{array}$} & D.6 Profitabilitas & E7. Rasio laba & $\begin{array}{l}\text { R7. Laba bersih / } \\
\text { Total aktiva }\end{array}$ & \\
\hline & $\begin{array}{l}\text { D.7 Distribusi Pendapatan } \\
\text { dan kekayaan }\end{array}$ & $\begin{array}{l}\text { E8. Pendapatan } \\
\text { Personal }\end{array}$ & $\begin{array}{l}\text { R8. Zakat / } \\
\text { Pendapatan bersih }\end{array}$ & \\
\hline & D8. Investasi pada sektor riil & $\begin{array}{l}\text { E9. investasi pada } \\
\text { sektor riil }\end{array}$ & $\begin{array}{l}\text { R0. Investasi sektor riil / } \\
\text { Total Investasi }\end{array}$ & \\
\hline
\end{tabular}

Ketiga maqasid dibagi menjadi 9 dimensi dan 10 elemen. Kesepuluh elemen diubah menjadi rasio kinerja, yaitu :

1. Education Individual (Mendidik individu) , dimensinya antara lain :

a. Pendidikan dan Pelatihan

Bank syariah memiliki kewajiban untuk meningkatkan skill dan pengetahuan pegawai dan masyarakat sekitar, hal ini di tunjukan dengan seberapa besar perhatian bank syariah terhadap beasiswa pendidikan bagi pegawai dan masyarakat.

b. Penelitian dan Pengembangan

Bank Syariah dituntut untuk ikut berperan serta dalam mengembangkan pengetahuan tidak hanya pegawainya tetapi juga masyarakat banyak.Peran 
ini dapat diukur melalui elemen seberapa besar bank syariah memberikan penelitian dan pengembangan.

c. Publikasi

Peran bank syariah dalam meningkatkan pengetahuan masyarakat khususnya tentang perbankan syariah adalah dengan melakukan sosialisasi dan publisitas perbankan syariah dalam bentuk informasi produk bank syariah, operasional dan system ekonomi syariah.

2. Establishing Justice (Menegakan Keadilan), dimensinya antara lain :

a. Pengembalian yang adil

Bank syariah dituntut untuk dapat melakukan transaksi secara adil yang tidak merugikan nasabahnya.Salah satu yang dapat dilakukan adalah dengan memberikan bagi hasil yang adil dan setara.

b. Produk dan jasa yang terjangkau

Elemen pengukuran yang dilakukan adalah seberapa besar pembiayaan dengan skim bagi hasil mudharabah dan musyarakah terhadap seluruh model pembiayaan yang diberikan bank syariah.

c. Penghapusan atas ketidakadilan

Riba (suku bunga) merupakan salah satu instrument yang dilarang dalam system perbankan dan keauangan syariah. Hal ini disebabkan riba memberikan dampak buruk terhadap perekonomian dan menyebabkan ketidakadilan dalam transaksi ekonomi.

3. Maslahah (kesejahteraan), dimensi pengukurannya antara lain :

a. Profitabilitas Bank

Semakin besar keuntungan yang diperoleh bank syariah maka akan berdampak pada peningkatan kesejahteraan tidak hanya pemilik dan pegawai bank syariah tetapi dapat berdampak pada semua stakeholder perbankan syariah.

b. Distribusi Pendapatan dan Kekayaan

Salah satu peran dari keberadaan bank syariah adalah mendistribusikan kekayaan pada semua golongan. Peran ini dapat dilakukan bank syariah melalui pendistribusian dana zakat yang dikeluarkan oleh bank syariah.

c. Investasi di sector riil

Prinsip dan akad-akad bank syariah dinilai lebih sesuai dalam pengembangan sector rill, sehingga tingkat pembiayaan bank syariah diharapkan lebih banyak pada sector riil tersebut seperti sector pertanian, pertambangan, konstruksi, manufaktur dan usaha mikro.

Dalam melakukan analisis menggunakan pendekatan Index Muqasyid Syariahada beberapa langkah pengukuran yang dilakukan yaitu menentukan rasio kerja, menghitung rasio kinerja bank syariah dengan menggunakan masing-masing, melakukan pembobotan masing-masing rasio kinerja. Berikut adalah langkah yang dilakukan dalam penelitian menggunakan Index Muqasyid Syariah, yaitu :

1. Penentuan Rasio Kerja

Dalam penentuan rasio kerja didasarkan pada ketersediaan data yang diperlukan dalam penelitan ini. Penelitian ini akan menggunakan sembilanrasio yang mewakili tiga variable yang akan digunkan di bank syariah. sembilan rasio tersebut adalah :

a. Beasiswa pendidikan dan pelatihan/ Total biaya

b. Biaya penelitan / Total Biaya

c. Biaya publikasi / total biaya

d. Bagi hasil yang belum dibagikan ( PER ) / Total Biaya

e. Mudhorobah dan musyarokah / Total investasi

f. Pendapatan tanpa bunga / Total Pendapatan 
g. Pendapatan bersih / Total Asset

h. Zakat / Laba bersih

i. Investasi sector riil / Total Investasi

2. Menentukan peringkat dari bank syariah berdasarkan Indikator Kinerja

Proses menentukan peringkat dari setiap bank syariah dilakukan melalui Indikator Kinerja (IK) setiap bank syariah. Proses tersebut menggunakan simple additive weighting method (SAW) dengan cara pembobotan, agregat dan proses menentukan peringkat (weighting aggregating and ranking processes).SAW merupakan metode multiple atribute decision making (MADM) yang dilakukan sebagai berikut.

Pengambil keputusan (decision maker) mengidentifikasi setiap nilai atribut.Dalam penelitian ini yang menjadi atribut adalah tiga tujuan maqashid syariah dan intra-atribut adalah 9 elemen dan 10 indikator kinerja (rasio) sebagaimana pada tabel sebelumnya.

Skor di perolehdengan cara mengalikan setiap rasio skala setiap atribut. Secara matematis, proses menentukan Indikator kinerja dan tingkat Index Muqasyid Syariahtersebut dapat dijelaskan sebagai berikut:

a. Tujuan pertama yaitu Tahzib al-Fard (Mendidik Individu) Indicator Kinerja (IK) untuk Tujuan 1 (Tl) adalah sebagai berikut:

$\mathrm{IK}(\mathrm{Tl})=\mathrm{IK} 11+\mathrm{IK} 21+\mathrm{IK} 31$

Dimana :

$\mathrm{IK} 11=\mathrm{W} 11 \times \mathrm{E} 11 \times \mathrm{R} 11$

$\mathrm{IK} 21=\mathrm{W} 11 \times \mathrm{xE} 21 \times \mathrm{R} 21$

IK31=W11xE31xR31

Dimana;

T1= Tujuan pertama dari maqashid syari'ah (Mendidik Individu)

W11= Bobot rata-rata untuk tujuan pertama (Mendidik Individu)

E11= Bobot rata-rata untuk elemen pertama tujuan 1(El.Diklat)
E21 = Bobot rata-rata untuk

elemen kedua tujuan 1(E2.

Penelitan)

E31 = Bobot rata-rata untuk elemen

ke elnpat tujuan 1 (E3. Publisitas)

R11= Rasio kinerja untuk elemen pertama tujuan 1

R21 = Rasio kinerja untuk elemen ketiga tujuan 1

R31 = Rasio kinerja untuk elemen ke empat tujuan 1

b. Tujuan kedua (T2) yaitu Iqamah alAdl (Menegakkan Keadilan). Indikator Kinerja (IK) untuk Tujuan 2 adalah sebagai berikut:

$\mathrm{IK}(\mathrm{T} 2)=\mathrm{IK} 12+\mathrm{IK} 22+\mathrm{IK} 32$

Dimana :

$\mathrm{IK} 12=\mathrm{W} 22 \times \mathrm{E} 12 \times \mathrm{R} 12$

$\mathrm{IK} 22=\mathrm{W} 22 \times \mathrm{E} 22 \times \mathrm{R} 22$

IK32 = W22 $\times$ E32 $\times$ R32

c. Tujuan ketiga (T3) yaitu Kepentingan Publik

Indikator Kinerja (IK) untuk tujuan 3 sebagai berikut :

$\mathrm{IK}(\mathrm{T} 3)=\mathrm{IK} 13+\mathrm{IK} 23+\mathrm{IK} 33$

Dimana :

$\mathrm{IK} 13=\mathrm{W} 33 \times \mathrm{E} 13 \times \mathrm{R} 13$

$\mathrm{IK} 23=\mathrm{W} 33 \times \mathrm{E} 23 \times \mathrm{R} 23$

$\mathrm{IK} 33=\mathrm{W} 33 \times \mathrm{E} 33 \times \mathrm{R} 33$

3. Menentuka Index Muqasyid Syariah

Index Muqasyid Syariah untuk setiap bank merupakan total semua kinerja indicator dari 3 tujuan maqasyid syariah, sehingga IMS setiap bank dapat dirumuskan sebagai berikut :

IMS = IK (T1)+IK ( T2) + IK ( T3)

Dengan kata lain IMS untuk setiap bank syariah adalah jumlah total dari indicator kinerja muqasyid syariah tujuan 1, tujuan 2 dan tujuan 2.

\section{Metode Penelitian}

Penelitian ini merupakan penelitian kuantitatif deskriptip dengan Jenis data yang digunakan dalam penelitian ini adalah data sekunder berupa data panel dengan 
menggunakan Index Muqasyid Syariah dengan variabel Mendidik Invividu, Menegakan Keadilan, Kepentingan Publik.

Populasi dalam penelitian ini adalah bank umum syariah yang terdaftar di Otoritas Jasa Keuangandalam kurun waktu penelitian tahun 2011-2015. Jumlah populasi dalam penelitian ini adalah sebanyak 12 bank.

\section{Hasil Penelitian}

Kinerja Muqasyid Syariah Bank Syariah
Untuk mengetahui sejauh mana Bank Syariah melaksanakan setiap tujuan tujuan tujuan maqasyid syariah dapat diukur melalui rasio kinerja muqasyid syariah yang telah di bagi menjadi tiga tujuan, yaitu :Mendidik Individu, Menegakan keadilan, dan Kemaslahatan.

Berikut adalah rasio kinerja maqasyid syariah 11 Bank Umum Syariah periode 2011 - 2015 untuk setiap tujuannya :

a. Tujuan pertama (Mendidik manusia)

Tabel: 2. Rasio kinerja muqasyid syariah tujuan pertama tahun 2011 - 2015

\begin{tabular}{lccc}
\hline BANK & \multicolumn{2}{c}{ RASIO MENDIDIK INDIVIDU } \\
& PENGETAHUAN & PENELITAN & PUBLISITAS \\
\hline MUAMALAT & 0.0170 & 0.0022 & 0.0451 \\
MANDIRI SYARIAH & 0.0133 & 0.0009 & 0.0241 \\
BUKOPIN SYARIAH & 0.0160 & 0.0001 & 0.0219 \\
BCA SYARIAH & 0.0149 & 0.0000 & 0.0116 \\
PANIN SYARIAH & 0.0114 & 0.0000 & 0.0151 \\
MAYBANK SYARIAH & 0.0032 & 0.0000 & 0.0090 \\
BRI SYARIAH & 0.0059 & 0.0000 & 0.0168 \\
BNI SYARIAH & 0.0046 & 0.0000 & 0.0062 \\
MEGA SYARIAH & 0.0040 & 0.0000 & 0.0060 \\
VICTORIA SYARIAH & 0.0007 & 0.0002 & 0.0004 \\
BJB SYARIAH & 0.0000 & 0.0005 & 0.0014 \\
\hline
\end{tabular}

Rasio kinerja muqasyid syariah tujuan pertama tahun $2011-2015$, sebagaimana table di atas, bank muamalat berada di peringkat pertama dalam tujuan pertama muqasyid syariah, sedangakan Bank
Victoria Syariah berada di peringkat ke 11. Rasio kinerja muqasyid syariah tujuan pertama tahun 2011 2015 tersebut dapat di gambarkan pada grafik berikut ini : 
Grafik1. Rasio kinerja muqasyid syariah tujuan pertama tahun 2011 - 2015

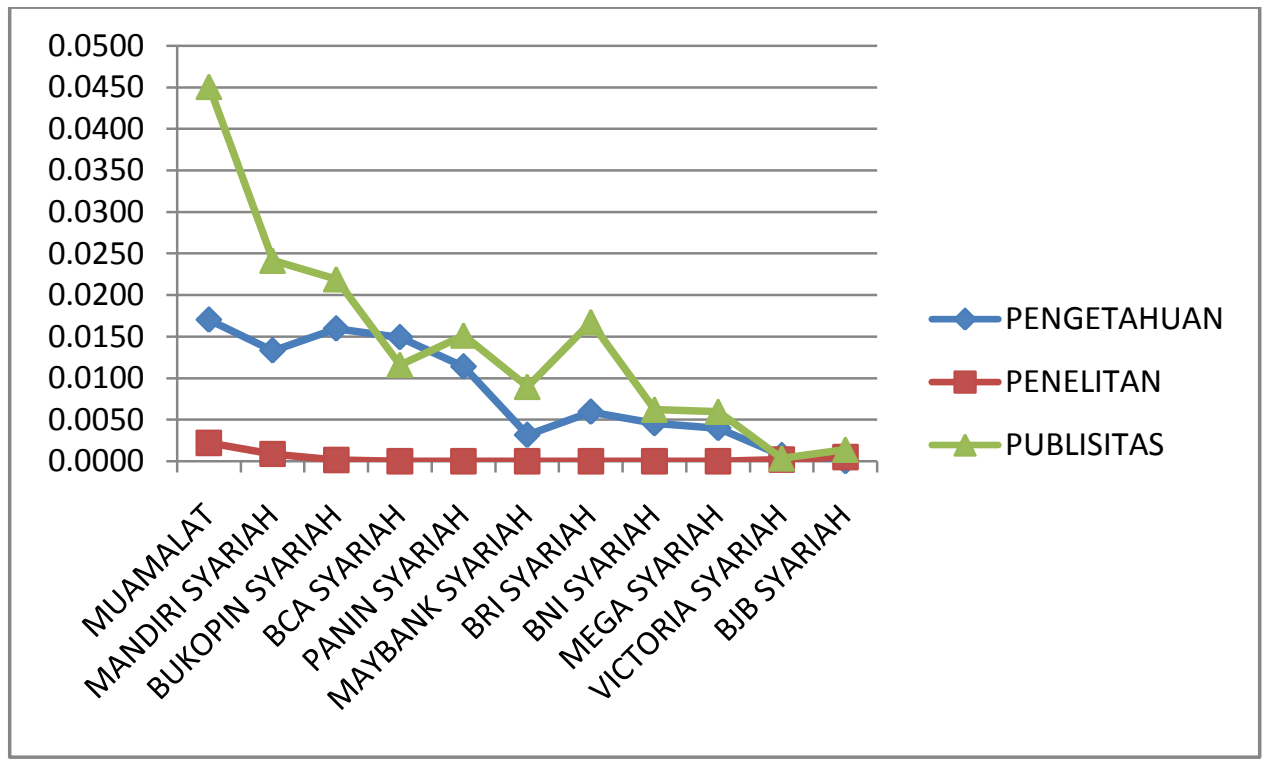

b. Tujuan kedua : Menegakan Keadilan

Tabel 3. Rasio kinerja muqasyid syariah tujuan kedua tahun 2011 - 2015

\begin{tabular}{lccc}
\hline \multicolumn{1}{c}{ BANK } & \multicolumn{3}{c}{ RASIO MENEGAKAN KEADILAN } \\
& KONTRAK ADIL & PRODUK TERJANGKAU & HAPUS TIDAK ADIL \\
\hline MUAMALAT & 0.0206 & 0.1676 & 0.3874 \\
PANIN SYARIAH & 0.0300 & 0.6585 & 0.5485 \\
VICTORIA SYARIAH & 0.0329 & 0.0267 & 0.3601 \\
BUKOPIN SYARIAH & 0.0054 & 0.2327 & 0.3523 \\
BCA SYARIAH & 0.0223 & 0.2030 & 0.3599 \\
BRI SYARIAH & 0.0200 & 0.2386 & 0.2274 \\
BJB SYARIAH & 0.0052 & 0.3003 & 0.2336 \\
BSM & 0.0106 & 0.3010 & 0.2399 \\
BNI SYARIAH & 0.0284 & 0.4792 & 0.0535 \\
MAYBANK SYARIAH & 0.0052 & 0.0059 & 0.2801 \\
MEGA SYARIAH & 0.0098 & 0.0047 & 0.0060 \\
\hline
\end{tabular}

Rasio kinerja muqasyid syariah tujuan kedua tahun 2011 - 2015, sebagaimana table di atas, bank muamalat berada di peringkat pertama dalam tujuan pertama muqasyid syariah, sedangakan Bank Victoria
Syariah berada di peringkat ke 11 . Rasio kinerja muqasyid syariah tujuan pertama tahun $2011-2015$ tersebut dapat di gambarkan pada grafik berikut ini : 
Grafik 2. Rasio kinerja muqasyid syariah tujuan kedua tahun 2011 - 2015

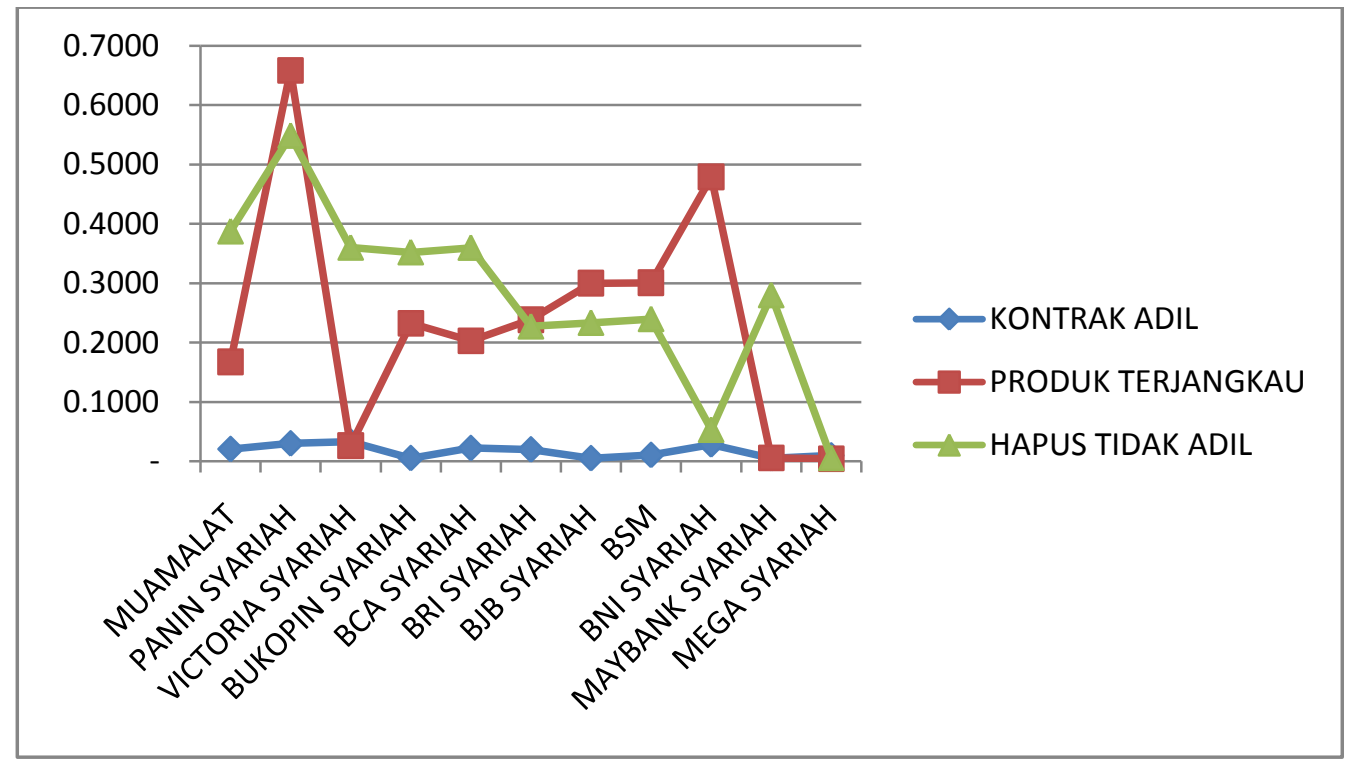

c. Tujuan ketiga : Kemaslahatan

Tabel 4. Rasio kinerja muqasyid syariah tujuan ketiga tahun 2011 - 2015

\begin{tabular}{lccc}
\hline BANK & \multicolumn{3}{c}{$\begin{array}{c}\text { RASIO MASLAHAH } \\
\text { DISTRIBUSI }\end{array}$} \\
\hline PANIN SYARIAH & 0.0100 & 0.0252 & 0.6585 \\
MANDIRI SYARIAH & 0.0078 & 0.0776 & 0.3010 \\
MUAMALAT & 0.0051 & 0.0469 & 0.1676 \\
BRI SYARIAH & 0.0042 & 0.0011 & 0.2386 \\
BUKOPIN SYARIAH & 0.0039 & 0.0000 & 0.2327 \\
BJB SYARIAH & 0.0018 & 0.0217 & 0.2392 \\
BNI SYARIAH & 0.0089 & 0.0526 & 0.1827 \\
BCA SYARIAH & 0.0053 & 0.0029 & 0.2030 \\
MEGA SYARIAH & 0.0117 & 0.0465 & 0.0047 \\
VICTORIA SYARIAH & 0.0090 & 0.0020 & 0.0267 \\
MAYBANK SYARIAH & 0.0110 & 0.0000 & 0.0059 \\
\hline
\end{tabular}

Rasio kinerja muqasyid syariah tujuan ketiga tahun 2011 - 2015, sebagaimana table 4.5, bank Panin Syariah berada di peringkat pertama dalam tujuan pertama muqasyid syariah, sedangkan Bank Maybank
Syariah berada di peringkat ke 11. Rasio kinerja muqasyid syariah tujuan pertama tahun 2011 - 2015 tersebut dapat di gambarkan pada grafik berikut ini : 


\section{Grafik 3. Rasio kinerja muqasyid syariah tujuan ketiga tahun 2011 - 2015}

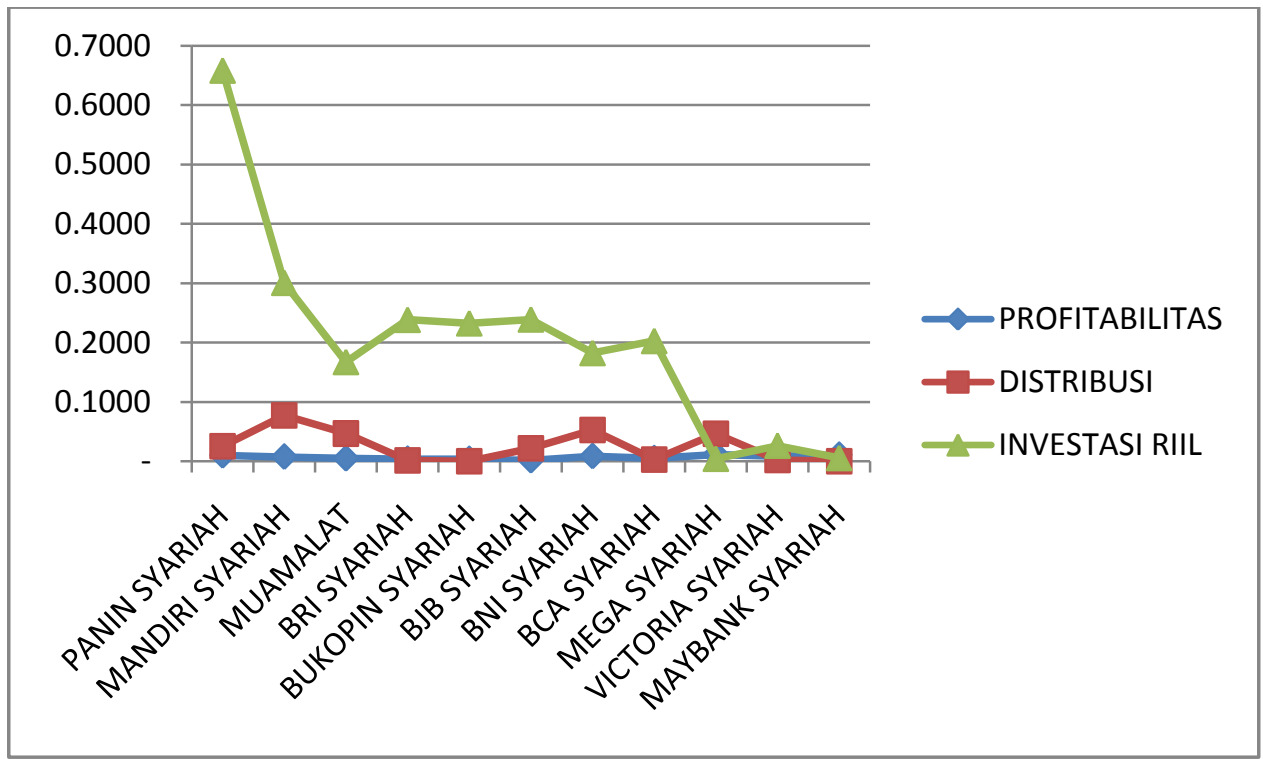

\section{Indikator Kinerja Bank Umum} Syariah

Setelah diketahui hasil penghitungan rasio kinerja muqasyid syariah, maka langkah selanjutnya adalah menentukan peringkat kinerja Maqasyid Syariah dari setiap Bank Umum Syariah. Proses penentuan kinerja ini dilakukan melalui Indikator Kinerja (IK) setiap Bank Umum Syariah.
Untuk mengetahui Indikator Kinerja digunakan metode Simple Additive Weighting Method (SAW) - (Hwang and Yoon, 1981) dengan cara pembobotan , agrerat, dan proses menentukan peringkat (Omar, 2008)

Berikut ini indicator kinerja setiap bank syariah berdasarkan tujuan tujuan maqasyid syariah :

Tabel 5. Indikator Kinerja tujuan 1 Maqasyid Syariah tahun 2011 - 2015

\begin{tabular}{lccc}
\hline BANK & \multicolumn{3}{c}{ KINERJA MENDIDIK INDIVIDU } \\
& PENGETAHUAN & PENELITAN & PUBLISITAS \\
\hline MUAMALAT & 0.0053 & 0.0002 & 0.0275 \\
BSM & 0.0041 & 0.0001 & 0.0147 \\
BUKOPIN & 0.0049 & 0.0000 & 0.0134 \\
BCA & 0.0046 & 0.0000 & 0.0071 \\
PANIN & 0.0035 & 0.0000 & 0.0092 \\
MAYBANK & 0.0010 & 0.0000 & 0.0055 \\
BRI & 0.0018 & 0.0000 & 0.0102 \\
BNI & 0.0014 & 0.0000 & 0.0038 \\
MEGA & 0.0012 & 0.0000 & 0.0036 \\
VICTORIA & 0.0002 & 0.0000 & 0.0002 \\
BJB & 0.0000 & 0.0000 & 0.0009 \\
\hline
\end{tabular}


Tujuan pertama yaitu mendidik individu dari tabel 5 dapat diketahui bahwa Bank Muamalat adalah bank umum syariah yang memiliki indicator kinerja tertinggi dalam menyalurkan donasi untuk tujuan pendidikan bagi masyarakat, memiliki alokasi dana untuk penelitian dan pengembangan yang paling tinggi di antara bank umum syariah lainnya dan memiliki indicator kinerja tertinggi dalam hal promosi tentang Bank syariah kepada masyarakat.

Tabel 6. Indikator Kinerja tujuan 2 Maqasyid Syariah tahun 2011 - 2015

\begin{tabular}{lccc}
\hline \multicolumn{1}{c}{ BANK } & \multicolumn{3}{c}{ KINERJA MENEGAKAN KEADILAN } \\
& KONTRAK ADIL & PRODUK TERJANGKAU & HAPUS TIDAK ADIL \\
\hline MUAMALAT & 0.0012 & 0.0805 & 0.1782 \\
PANIN & 0.0018 & 0.3161 & 0.2523 \\
VICTORIA & 0.0020 & 0.0128 & 0.1656 \\
BUKOPIN & 0.0003 & 0.1117 & 0.1620 \\
BCA & 0.0013 & 0.0974 & 0.1656 \\
BRI & 0.0012 & 0.1145 & 0.1046 \\
BJB & 0.0003 & 0.1442 & 0.1075 \\
BSM & 0.0006 & 0.1445 & 0.1103 \\
BNI & 0.0017 & 0.2300 & 0.0246 \\
MAYBANK & 0.0003 & 0.0028 & 0.1289 \\
MEGA & 0.0006 & 0.0022 & 0.0027 \\
\hline
\end{tabular}

Kinerja pertama dalam melaksanakn tujuan kedua yaitu Kontrak yang adil yang di cerminkan dari penggunaan PER terlihat bahwa Bank Victoria Syariah lebih unggul dalam menempatkan bagi hasil yang belum di bagikan. Elemen kedua yaitu Produk yang terjangkau yang dijelaskan oleh rasio pembiayaan dengan skim bagi hasil (muharobah dan musyarokah) terhadap skim lainnya, pada elemen ini Bank Panin Syariah mengalokasikan pembiayaan mudhorobah dan musyarokah lebih tinggi dibandingkan bank umum syariah lainnya. Sedangkan pada Elemen ketiga terlihat bahwa bank Panin syariah lebih baik dalam mencapai pendapatan non bunga.
Dari table di bawah terlihat bahwa Bank Panin syariah lebih baik dalam aspek profitabilitas bank syariah.Sedangkan Bank Syariah Mandiri memiliki indikator kinerja yang baik dalam membayar zakat dari laba yang diperoleh bank.Dan Bank Panin Syariah lebih baik dalam menyalurkan pembiayaan ke sektor riil dibandingkan dengan bank syariah lainnya.Secara umum bank Panin Syariah lebih baik dalam tujuan maqasyid yang ketiga yaitu Maslahat. 
Tabel 7. Indikator Kinerja tujuan 3 Maqasyid Syariah tahun 2011 - 2015

\begin{tabular}{lccc}
\hline BANK & & KINERJA MASLAHAH & \\
& PROFITABILITAS & DISTRIBUSI & INVESTASI RIIL \\
\hline PANIN & 0.0017 & 0.0045 & 0.4280 \\
BSM & 0.0013 & 0.0140 & 0.1956 \\
MUAMALAT & 0.0009 & 0.0084 & 0.1089 \\
BRI & 0.0007 & 0.0002 & 0.1551 \\
BUKOPIN & 0.0007 & - & 0.1513 \\
BJB & 0.0003 & 0.0039 & 0.1555 \\
BNI & 0.0015 & 0.0095 & 0.1188 \\
BCA & 0.0009 & 0.0005 & 0.1320 \\
MEGA & 0.0020 & 0.0084 & 0.0030 \\
VICTORIA & 0.0015 & 0.0004 & 0.0174 \\
MAYBANK & 0.0019 & - & 0.0038 \\
\hline
\end{tabular}

Index Muqasyid Syariah

Index Muqasyid Syariah merupakan total penjumlahan indicator
IMS. Berikut ini table Index Muqasyid Syariah bank umum Indonesia periode $2011-2015$ :

Tabel 8: Index Muqasyid Syariah Bank Syariah 2011 - 2015

\begin{tabular}{lccccc}
\hline BANK & \multicolumn{3}{c}{ INDEKS MUQASYID SYARIAH } & TOTAL & Peringkat \\
& INDIVIDU & KEADILAN & MASLAHAH & & \\
\hline MUAMALAT & 0.0329 & 0.2599 & 0.1183 & 0.4111 & 4 \\
MANDIRI SYARIAH & 0.0189 & 0.2554 & 0.2109 & 0.4853 & 2 \\
BUKOPIN SYARIAH & 0.0183 & 0.2741 & 0.1520 & 0.4444 & 3 \\
BCA SYARIAH & 0.0117 & 0.2643 & 0.1334 & 0.4094 & 6 \\
PANIN SYARIAH & 0.0128 & 0.5702 & 0.4343 & 1.0172 & 1 \\
MAYBANK SYARIAH & 0.0064 & 0.1320 & 0.0057 & 0.1441 & 10 \\
BRI SYARIAH & 0.0121 & 0.2204 & 0.1560 & 0.3884 & 7 \\
BNI SYARIAH & 0.0052 & 0.2563 & 0.1297 & 0.3913 & 8 \\
MEGA SYARIAH & 0.0049 & 0.0056 & 0.0134 & 0.0238 & 11 \\
VICTORIA SYARIAH & 0.0005 & 0.1804 & 0.0193 & 0.2002 & 9 \\
BJB SYARIAH & 0.0009 & 0.2519 & 0.1597 & 0.4125 & 5 \\
\hline
\end{tabular}

Dari tabel diketahui bahwa pelaksanaan tujuan pertama dilakukan paling baik oleh Bank Muamalat, pada tujuan kedua pelaksanaan terbaik diraih Bank Panin Syariah, sedangkan pelasanaan terbaik tujuan ketiga
(Maslahah) terbaik diraih oleh Bank Panin Syariah. Dan secara umum untuk pelaksaan Index Muqasyid Syariah nilai tertinggi untuk semua tujuan adalah Bank Panin Syariah. 
Perkembangan muqasyid syariah bank syariah di Indonesia, dapat di gambarkan pada grafik berikut ini :

Grafik 4: Index Muqasyid Syariah Bank Syariah 2011 - 2015

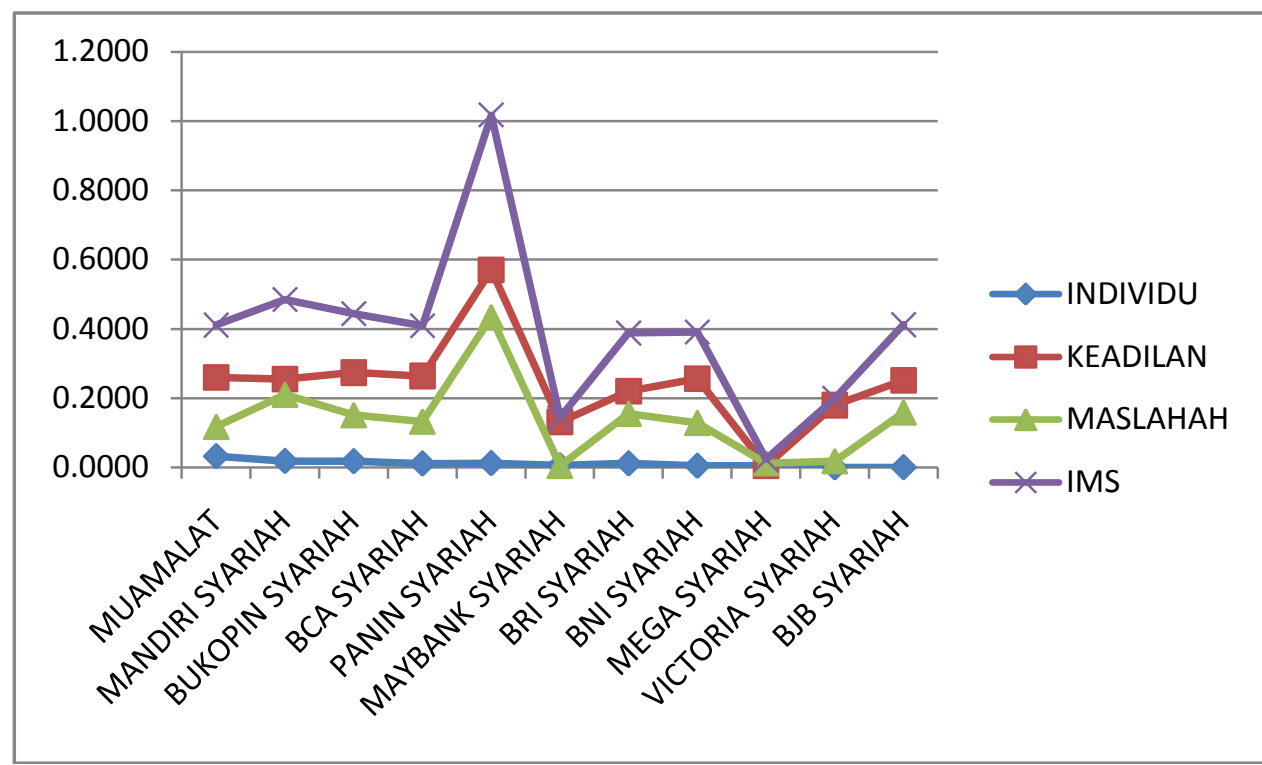

\section{Pembahasan penelitian}

Perkembangan muqasyid syariah bank syariah di Indonesia periode 2011 2015, sebagaimana table 4.9, bank panin syariah berada di peringkat pertama dalam Index Muqasyid Syariah, adapun pembahasannya sebagai berikut :

1. Bank Panin Syariah ( BPS )

Bank Panin Syariah berada di peringkat pertama dalam Index Muqusyid Syariah periode 2011 - 2015, hal ini tidak lepas dari dominasi pembiayaan yang disalurkan selama periode 2011 - 2015 . Walaupun angka IMS paling tinggi, BPS tidak melaporkan zakat di tahun 2011 2013 dan baru mengeluarkan zakat di tahun 2014.

2. Bank Syariah Mandiri

Bank Syariah Mandiri berada di tingkat ke dua dalam Index Muqasyid Syariah periode 2011 - 2015. Hal ini dikarenakan ,BSM menunjukan kepeduliannya terhadap pendidikan melalui LAZNAS BSM, BSM juga bank yang mengalokasikasikan ke dana penelitian dan juga mengalokasikan dana cukup besar untuk publisitas ke masyarkat. Akan tetapi di dalam skim pembiayaan BSM diharapkan untuk memperbesar pembiayaannya karena tiap tahun mengalami kecenderungan penurunan, di samping itu juga BSM setiap tahunnya rutin untuk mengeluarkan zakat yang di distribusikan oleh LAZNAS BSM.

3. Bank Bukopin Syariah (BBS )

Bank Bukopin Syariah berada di tingkat ke tiga dalam Index Muqasyid Syariah periode 2011 - 2015. Hal ini dikarenakan di tahun 2015 pembiayaan Bank Bukopin mengalami pertumbuhan yang cukup signifikan dibandingkan tahun sebelumnya, sehhingga menyebabkan nilai IMS dari BBS naik ke posisi ke tiga. Dan Bank Bukopin dalam periode 2011 2015 konsisten untuk meningkatkan SDM di perusahaan dan memberikan beasiswa ke masyarakat, juga di tahun 2015 investasi riil ke masyarakat yang dikeluarkan oleh Bank Bukopin mengalami pertumbuhan yang signifikan.

4. Bank Muamalat Indonesia ( BMI )

Bank Muamalat berada di peringkat ke empat Index muqasyid Syariah periode 2011 - 2015. Terbaik dalam mendidik individu tidak diimbangi dengan investasi riil di masyarakat, karena pada tahun 2015 Bank Muamalat mengalami penurunan dalam menyalurkan investasi riil di masyarakat dan juga tren penurunan dalam penyaluran pembiayaan dari tahun 
2012 - 2015. Di samping itu juga BMI mengeluarkan zakat tertinggi dibandingkan bank lainnya selama periode 2011 - 2015 .

5. Bank Jabar dan Banten Syariah ( BJBS ) BJBS berada di peringkat ke lima dalam Index Muqasyid Syariah periode 2011 2015. Posisi tersebut didukung oleh pembiayaan BJBS dengan porsi terbesar ke 6 dalam penyaluran pembiayaan dan penyaluran investasi riil ke masyarakat, juga mengalokasikan dana penelitan pada tahun 2012. Disamping keunggulannya tersebut BJBS masih memiliki kekurangan, yaitu tidak membayar zakat tahun di tahun 2012 dan 2013 dan tidak mengalokasikan biaya untuk pendidikan dan pelatihan.

6. BCA Syariah

BCA Syariah berada di peringkat ke enam dalam Index Muqosyid syariah periode 2011 - 2015. Hal ini dikarenakan rendahnya penyaluran investasi riil selama periode $2011-2015$ di bandingkan penyaluran pembiayaan ke perusahaan. BCAS juga rutin mengeluarkan zakat setiap tahunnya, akan tetapi BCAS diharapkan memberikan alokasi penelitian, karena selama periode 2011 - 2015 BCAS tidak mengeluarkan biaya penelitian.

7. Bank Rakyat Indonesia Syariah (BRIS )

BRIS menempati posisi ke tujuh dalam Index Muqasyid Syariah periode 2011 2015, Hal ini dikarenakan menurunnya pengalokasian pembiayaan dari tahun 2011 - 2015 yang sebelumnya $34 \%$ di tahun 2011 menurun sampai $15 \%$ di tahun 2015. Selain itu BRIS memiliki alokasi dana terbesar untuk pendidikan dan publikasi, juga BRIS rutin mengeluarkan zakat setiap tahunnya.

8. Bank Negara Indonesia Syariah ( BNIS ) BNIS menempati posisi ke delapan dalam Index muqasyid syariah periode 2011 2015, Posisi BNIS yang dibawah rata rata tersebut disebabkan oleh rendahnya skim pembiayaan selama periode 2011 2015. Walaupun memiliki kelemahan dalam skim pembiayaan, BNIS memiliki keunggulan lain dalam maqasyid syariah, seperti adanya donasi di tiap tahunnya, selain itu BNIS juga memiliki rasio profitabilitas, zakat, dan investasi sector riil dengan baik, tetapi keunggulan tersebut masih kurang cukup untuk meningkatan nilai Index Muqasyid Syariah.

9. Bank Victoria Syariah (BVS)

BVS menempati posisi ke Sembilan dalam Index Muqasyid Syariah periode 2011 - 2015. Hal ini dikarenakan naiknya pendapatan non bunga dari tahun 2013 2015. Factor yang menyebabkan BVS berada di posisi ke Sembilan adalah rendahnya investasi sector riil selama periode 2011 - 2015 yang mencapai 2,7 $\%$ disamping itu juga mengalami kerugian di tahun 2014 dan 2015 sehingga profitabilitas negative. Rendahnya IMS pada BVS juga disebabkan karena BVS tidak melaporkan zakat pada tahun 2011 dan 2012 dan tidak mengalokasikan untuk biaya penelitian dan pelatihan selama periode 2011 - 2015.

10. Bank MayBank Syariah (BMBS)

BMBS berada di posisi ke sepuluh dalam Index Muqasyid Syariah periode 2011 - 2015. Hal ini dikarenakan rendahnya porsi pembiayaan bagi hasil dibandingkan dengan skim jual beli dan ijarah di BVS, sehingga menyebabkan pembiayaannya lebih kecil dibandingkan bank lainnya .Selain itu investasi sekor riil selama periode 2011 - 2015 mencapai $0,4 \%$ hal ini disebabkan karena BMBS lebih banyak menginvestasikan ke bidang keuangan. Factor lainnya adalah BMBS tidak mengalokasikan zakat selama periode 2011 - 2015. Dan pada tahun 2015 mengami kerugian yang disebabkan tingginya nilai tukar rupiah terhadap dolar.

11. Bank Mega Syariah (BMS)

BMS berada di posisi ke sebelas dalam Index Muqasyid Syariah periode 2011 2015. Hal ini dikarenakan rendahnya skim pembiayaan yang hanya mencapai $0,5 \%$ selain itu BMS memiliki 
pengalokasian rendah terhadap pendidikan dan pelatihan, publikasi selama periode 2011 - 2015 yang hanya $0,4 \%$ dan $0,6 \%$. Akan tetapi dalam pembayaran zakat, BMS konsisten membayar zakat dari tahun 2011 sampai 2015 walaupun komponen nilai IMS yang lainnya kecil.

\section{Penutup}

Penelitian ini memberikan gambaran bahwa pelaksaan muqasyid syariah dapat diukur dalam perbankan syariah. Pelaksanaan muqasyid syariah merupakan kewajiban bagi setiap individu / lembaga ( bank syariah ) untuk memberikan kenyamanan bagi nasabah bahwa bank syariah tersebut bisa memberikan keyakinan bahwa bank syariah memang berbeda dengan bank konvensional, namun sampai saat ini belum ada kewajiban dari bank syariah untuk mengukur kinerjanya dengan muqasyid syariah.

Dari penelitan ini terlihat bahwabank Paninsyariah berada di peringkat ke satu, sedangkan bank Mega syariah menempati peringkat ke 11 untuk pengukuran Index Muqasyid Syariah. Dan setiap bank syariah memiliki kelebihan masing - masing dalam melaksankan elemen - elemen muqasyid syariah, dan kekurangannya seperti tidak memiliki rasio muqasyid syariah dari laporan keuangannya seperti biaya penelitian dan zakat. Hal ini disebabkan karena laporan keuangan bank tidak mewajibkan adanya komponen elemen tentang muqasyid syariah yang harus dilaporkan oleh bank syariah.

\section{Daftar Pustaka}

Adiwarman Karim.(2010). Bank Islam Analisis Fiqih dan Keuangan.PT Raja Grafindo Persada: Jakarta

Ahmad Al Mursi Husain Jauhar.(2013). Maqashid Syariah. Penerbit Amzah: Jakarta

Ascary.(2012). Akad dan Produk Bank Syariah di Indonesia.Gramedia: Jakarta.
Afrinaldi, 2014. Analisa Kinerja Perbankan Syariah Indonesia ditinjau dari Maqasid Syariah :PendekatanSyariah Maqasid Index ( SMI ) dan profitabilitas bank syariah. Islamic economis \& finance (IEF) : universitas trisakti.

Al Mubarak, T \&Osmani, N.M., 2010. Applications of Maqasid al Shariah and Maslahah in Islamic Banking .International Seminar on Islamic Finance in Inda, 4 -6 oktober 2010, Koaci ,India

Antonio, M.S, Sanrego, Yuliar D dan Taufiq, M. 2012. An Analysis of Islamic BankingPerformance : Muqashid Index Implementation in Indonesia and Jordania. Journal of Islamic Finance, vol 1 no. 1 (2012) : IIUM, Institute of Islamic Banking and Finance.

Bedoui, M. H, 2012. Sharia Based Eticical Performance Measurement Faramework. Chair for Ethics and Financial nor universite pars.

Bedoui, M.H.\&Mansourt, W. 2013.Islamic Bank Performance and Maqasid Syariah.Asia Pacific Economic Association Conference, Osaka Jepang, 27 - 28 Juli 2013.

Chapra, U. (2001). The Future of Economics: An Islamic Prespective. The Islamic Foundations. Leicester. United Kingdom

Dusuki, Asyraf, Wajdi and Irwani, A.N., 2007, Maqasyd Syariah ,Maslahah, and Corporate Social Responsibility, The American Jurnal of Islamic Social Science, 24 (1) , 25 - 42.

Hameed, Shahul, Ade, Wirman, Bachtiar, Alrazi, Mohd, Nazli dan Sigit Pramono (2004) . Alternative disclausure and performance measures of Islamic Banks Performance And maqashid Al Shariah. Makalah disampaikan pada $2^{\text {nd }}$ International conference on Administrative Sciences.di King University of Petrolium and Minerals.Arab Saudi 19-21 April 2004 Jumingan.(2006). Analisis Laporan Keuangan.Jakarta : PT Bumi Aksara 
Mohammed, Dzuljastri dan Taib (2008).The Performance of Islamic Banking Based on The Maqashid Frammework.Makalah disampaikan pada IIUM International Accounting Conference (INTAC IV). Putra Jaya Marroit. Malaysia. 25 Juni 2015

Mohammed, Mustafa Omar dan Taib, Fauziah Md. ( 2009). Testing the performance Measured Based on maqashid Framework Shariah (PPMS). Model on 24 Selected Islamic and Conventional Bank.

Mughess, Saukat. (2008). The Recent Financial Growth of Islamic Banks and Their Fulfilment of maqashid al-Shariah Gap Analysis :INCEIF

Mohammad, M.O.,Razak, Dzuljastri Abdul dan Taib, Fauziah md , 2008, The Performance Measures of Islamic Banking Based on the Maqasid Framework. IIUM Internasional Accounting Conference (INTAC IV )

Mohammad, M.O., dan Shahwan, Sahidwati. 2010. The Objective of Islamic Banking in Light of Maqasyd al Shariah : a critical review,middle eats jornalof scientific research 13 .

Otoritas Jasa Keuangan. (2016). Statistik Perbankan Syariah.Diakses melalui http:// www.ojk.go.id pada pukul 09.00 tanggal 27 Agustus 2016

Syafi'i Antonio. (2001). Bank Syariah; dari Teori ke Praktik. Gema Insani: Jakarta.

Syafi'i Antonio dan Prawiraatmadja. (2000). Apa dan Bagaimana Bank Islam. Dana Bhakti Prima : Yogyakarta.

Syafi'i Antonio, Sanrego dan Taufiq (2012). An Analysis of Islamic Banking Performance: maqashid Index Implementation in Indonesia and Jordania. Journal Of Islamic Finance. Vol.1(2): 12-29.

Veitzal Rifai. (2012). Banking and Finance. BPFE: Yogyakarta

Zakaria, M., 2014.The Influence of Human Needs in the Perspective of Maqasid Alsyariah on Zakat Distribution Effectiveness. Asian Social Science, vol 10, no. 3 